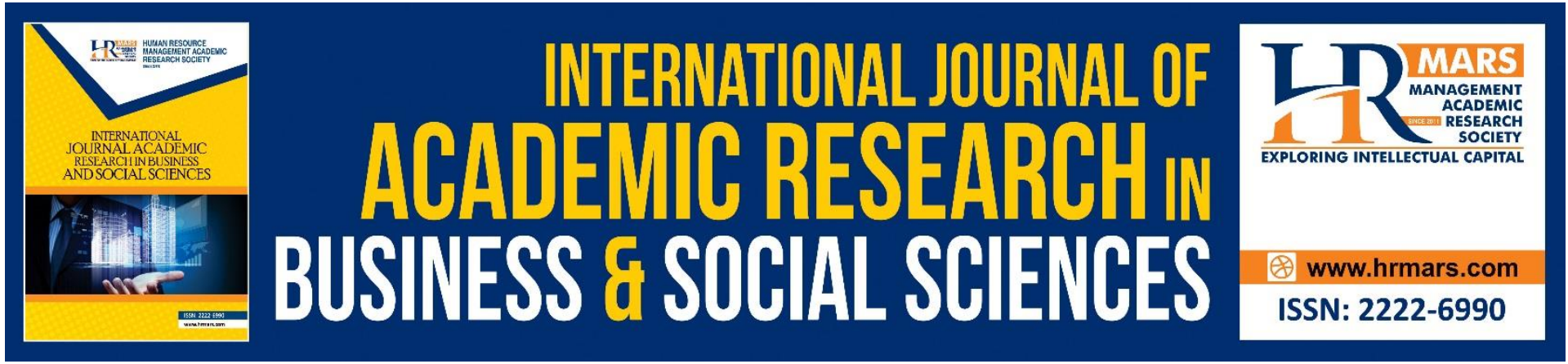

\title{
An Analysis of Human's Needs from Islamic Perspectives in Cucu Tuk Wali by Abu Hassan Morad
}

Nur Azimah bt Abdul Aziz @ Mohd Salleh, Halis Azhan bin Mohd Hanafiah, Roslina binti Abu Bakar

To Link this Article: http://dx.doi.org/10.6007/IJARBSS/v11-i8/10604

DOI:10.6007/IJARBSS/v11-i8/10604

Received: 29 June 2021, Revised: 30 July 2021, Accepted: 16 August 2021

Published Online: 27 August 2021

In-Text Citation: (Salleh et al., 2021)

To Cite this Article: Salleh, N. A. bt A. A. @ M., Hanafiah, H. A. bin M., Bakar, \& Abu, R. binti. (2021). An Analysis of Human's Needs from Islamic Perspectives in Cucu Tuk Wali by Abu Hassan Morad. International Journal of Academic Research in Business and Social Sciences, 11(8), 1526-1540.

Copyright: @ 2021 The Author(s)

Published by Human Resource Management Academic Research Society (www.hrmars.com)

This article is published under the Creative Commons Attribution (CC BY 4.0) license. Anyone may reproduce, distribute, translate and create derivative works of this article (for both commercial and non-commercial purposes), subject to full attribution to the original publication and authors. The full terms of this license may be seen at: http://creativecommons.org/licences/by/4.0/legalcode

Vol. 11, No. 8, 2021, Pg. 1526 - 1540

Full Terms \& Conditions of access and use can be found at http://hrmars.com/index.php/pages/detail/publication-ethics 


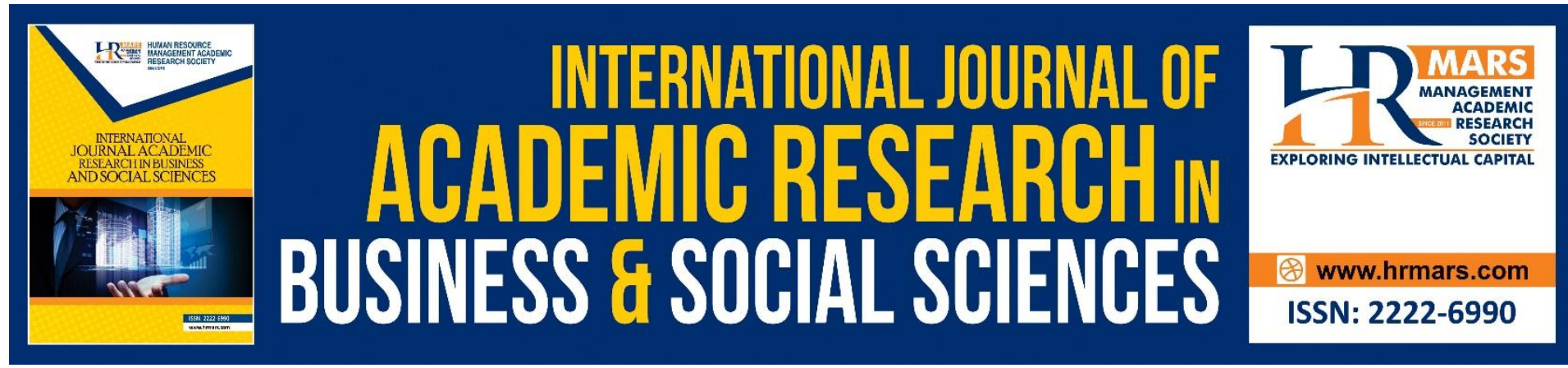

\title{
An Analysis of Human's Needs from Islamic Perspectives in Cucu Tuk Wali by Abu Hassan Morad
}

\author{
Nur Azimah bt Abdul Aziz @ Mohd Salleh \\ Kementerian Pelajaran Malaysia \\ Email: nurazimah.abdulaziz.mohdsalleh@gmail.com
}

Halis Azhan bin Mohd Hanafiah, PhD

Malay Language Department, Faculty of Modern Languages and Communication, University

Putra Malaysia, Serdang, 43400 Serdang, Malaysia

Email: halis_azhan@upm.edu.my

\section{Roslina binti Abu Bakar, PhD}

Malay Language Department, Faculty of Modern Languages and Communication, University

Putra Malaysia, Serdang, 43400 Serdang, Malaysia

Email: Iynabubakar@upm.edu.my

\begin{abstract}
This paper aims to analyze human's needs from Islamic perspectives, as illustrated in a young adult novel, Cucu Tuk Wali by Abu Hassan Morad. It is a general belief that any prose fiction would utilize conflicts to generate stories. This, however, can only be materialized if such conflicts manage to highlight the actual needs of the protagonist. Therefore, the study would evolve around Liza, a young adult who is good in academics and personality, yet an unfortune one too as she has to deal with a number of conflicts in her life. Becoming a college dropout, the people of her hometown start to look down at her, none belief in her capability. At home, she feels unease as her father has just remarried her once school classmate. Liza needs to overcome these obstacles first before rectifying everything, and achieves several goals that were once seemed achieveable. In line with this, the study would scrutinize the Islamic theory of human's needs, as proposed by Fakhr al-Din al-Razi (or widely known as al-Razi). The theory encompasses five components of human needs, namely al-U'budiyyah (the needs for devotions), Talab al-Isti'anah (the needs for supports), Talab of Istaqamah (the needs of right paths), Talab of Hidayah (the needs for guidances) and Talab of Ni'mah (the needs for rewards). These needs are said to be circulating in a man through out his life and he would always try to achieve them simultaneously. This study later finds out that in her effort to overcoming these conflicts and achieving her needs, Liza as the protagonist of the novel portrays good and favourable characterictics of a caliph and a servant of God. Due to these,
\end{abstract}


she is said to possess all the five forms of needs of outlined by al-Razi in his Islamic theory of human's needs.

Keywords: Human's Need, Islam, Novel, Young Adult, Al-Razi

\section{Introduction}

The novel writing in Malaysia has flourished since the beginning of 1990s and more recently, there would be a betterment in scale through the involvement of more writers from various backgrounds (Hashim, 2007: 32). According to Hashim Ismail, the involvements of these writers bring out diversity of techniques and styles in novel writing. What is more interesting here is that the diversity of techniques and styles would also help in escalating meanings in the works. Besides novelty in ideas and techniques, such writing would impose the values of knowledge, hence would be good enough to be used as educational tools. When relating this to the young adult novelists, Nor (2006: 220) believes that such writers who have strong beliefs in God would place Islamic values and knowledge in the writing, as it is becoming a good mean to preach readers on Islam. In other words, the young adult novels can become tools to encourage Islamic movement (or syiar), which encompassing the preach in the Quran and the hadith, and consequently lead Muslims to display the values of uniqueness, purity, and excellence of Islam in everyday's life (Jumali, 2009: 35).

This paper aims to discuss the human's need from the Islamic perspectives in a novel titled Cucu Tuk Wali by Abu Hassan Morad. In this regard, the studies on human's needs have been previously conducted by some researchers. Among them are Halis (2002); Julia (1997) who discussed human's needs in selected Malaysian young adult novels by scrutinizing Maslow's theory of the hierarchy of human's needs. Nurhamizah Hashim (2015) later has discussed human's needs by utilizing the theory of the hierarchy of adolescent needs, adopted from the same Maslow's theory of hierarchy of human needs. Apart from these, the study on human's needs from the Islamic perspectives by al-Razi have also been conducted by Halis, Arbaie' \& Nik (2017), focussing on the needs of selected young adult characters in the novel Rona Bhosporus by Zaid Akhtar. Besides the studies, the novel Cucu Tuk Wali alone has also attracted some researchers, such as Jumali \& Che (2010); Jumali (2011). In the former, Jumali $\&$ Che (2010) discuss various issues on community, particularly on the social and the cultural aspects which reflects the young adults' lives in the respective. In the latter, Jumali (2011) discusses the influence of urbanization in the same novel. This paper, thus, intends to study the human's needs from the Islamic perspectives in the novel Cucu Tuk Wali, focussing on the forms Al-'Ubudiyyah (the needs for devotions), Talab al-Isti'anah (the needs for supports), Talab Istiqamah (the needs for the right paths), Talab Hidayah (the needs for guidances) and Talab Ni'mah (the needs for rewards). These five components of needs become the essence of the Islamic theory of human's need as proposed by al-Razi.

This discussion examines the needs of the protagonist from an Islamic perspective in the novel Cucu Tuk Wali. As mentioned earlier, the protagonist is a young adult named Liza. "Need" is defined in Kamus Dewan (2007: 526) as a "wish", or a "deep desire" (of someone to achieve something). The one's tendency to achieve the "need" usually would lead to an action, verbally or physically, a genuine consideration that comes together with a reason. A "need" is often considered subjective (as it derives basically on the views (feelings) of people who observe or evaluate) as it is closely related to internal and external factors such as instincts, passions, goals, impulses, suggestions, expectation of benefits, rejecting disadvantages, understanding, rational and belief. However, if "need" is associated with human 
responsibility, the degree of responsibility can be justified through the concepts and activities (Muhammad, Indriaty \& Ibrahim, 2014: 58).

Meanwhile, according to Tang (1990: 9-11), "need" is a stimulus to represent the desire in a person to achieve a purpose in his life. This desire to achieve the "need" occurs when there is a shortage in life (of necessities of life such as food, drink, shelter, and clothing). This explains that the "need" is a stimulus in one's body that reacts when the "need" is insufficient. Therefore, the term "need" in this discussion can be summarized as a stimulus that arises as a wish, or a desire to be achieved something by someone and this is due to some related internal and external factors, such as instincts, passions, goals, impulses, suggestions, expectations of benefits, rejecting disadvantages, understanding, rationality and belief.

Based on the protagonist's conflicts that have been mentioned, the scope of the discussion would cover her (Liza's) "needs". The novel indicates that Liza is the younger of two siblings and she lives with her sister, Kak Bibah. She appears in the novel as a Muslim who is very responsible, diligent and resilient in facing the difficulties of her life. The novel implies that the conflicts start to occur in Liza's life once her father, Haji Lah, remarried after the death of her mother. Liza is said to be unable to accept the fact that Zainab, a young woman in the same hometown and once rivalled her in school, has turned out to be her stepmother. Soon after the wedding, Liza does not return to her father's house anymore and she prefers to stay at her sister's house, even after leaving the university.

Besides the problem in her family, Liza also runs into difficulties with the hometown folks who mostly ignorant, yet prefer to quickly jump into conclusion for whatever gossips they just know. They simply belives that Liza is a just university dropout. It is always a general belief, that a student who does not complete his/her studies in university is considered a failure before the eyes of the people. In this case, Liza was once a student studying agriculture in Universiti Putra Malaysia (one of the leading universities in Malaysia) and as a result of the unexpected return, she wishes to make a comeback, reshuffling her plan and believes that she should start by merging herself in the local agricultural projects. This, however, is easier said that done. Although some of the youths welcome her, some others do not. A young man who rivals her is Azhar, and keeps bad-mouthing her as if being a university dropout is a sin. Azhar never believes that she can carry out lot of duties, and the agricultural projects that follow may turn out to be a failure as well. As a result, a number of people start to look down at Liza, including Mak Kiah, her closest neighbour.

Other than that, Liza is also facing an unexpected conflict when Safuan, her once special boyfriend in university days, suddenly show up in the village for an internship training. Her life simply turns upside down since she has just been engaged to Amir, a local personality who is keen to become a politician. Since then, Safuan has never came into her mind anymore as she strongly believes that Amir is destined to her future husband. Besides, there is nothing else for her to hope for. They break up when Safuan never listens to her pleas to worship Allah, God the Almighty. Instead, he accused her to be religiously extreme. As a result, they take different paths. The life of Liza has twists and turns already, and she knows that she has to be resilient and strong when facing the difficulties. 


\section{Al- Razi's Theory of Human's Needs}

The study would emphasize on the psychological aspects of human beings, particulary on the young adult psychological development as this is the character who is trying to achieve the needs in the novel. Since the protagonist is a Muslim, the study would scrutinize the Islamic theory of human psychology proposed by Fakhr al-Din al-Razi or widely known as Imam alRazi. Imam al-Razi is one of prominent Islamic scholars of all time and well known as a mufassir, mutakallim, faqih, usuli, "writer" (adib), "poet" (sha'ir) and "doctor" (tabib). He spent his precious time in the field of 'intellect' (al-ma'qul), the study of al-manqul, the studies of sharia, law, and the study of 'physics' (al-riyadiyah) (Mohd, 2011: 14).

This Islamic theory of human's need is based on the human's desire to achieve a sublime life, to be close to Allah (the God Almighty worshipped by Muslims). This theory is first dictated in Ma'alim Usul al-Din by al-Razi which emphasizes the psychological aspect of the real need and desire of human beings to determine the desired personality as a Muslim. This theory is solely basing on Tawhid, which emphasizes that every Muslim must have a strong belief in Allah, God Almighty and would always worship Him. The five components of needs outlined in the theory, and they integrate and complement each other, as all of them together would satisfy every Muslim when performing good deeds.

Al-Razi (1978: 76) explains that there are a number of stages in one's soul that would shape his need to achieve pleasure and perfection in life. Moreover, Al-Razi stresses that there is no clear difference in achieving pleasure and perfection in life since the good deeds would please every man (the feeling of pleasure). This explains that in achieving such pleasure, a human tends to obtain something in his life. Al-Razi (2000: 81) also mentions that perfection is a necessity in every human's soul. For Al-Razi (2000: 83), to achieve this, every man is obliged to regularly perform good manner, either verbally or physically.

Hanapi further discusses this theory by stressing that al-Razi has outlined five important components, structured here as the five pillars (of the theory) to achieving the needs. Al-Razi's Islamic theory of human's needs (pp. 168, 189, 247-253, 262-266) introduces these five components (pillars) as al-'Ubudiyyah (the needs for devotions), Talab al-Isti'anah (the needs for supports), Talab Istiqamah (the needs for the right paths), Talab of Hidayah (the needs for guidances) and Talab of Ni'mah (the needs for rewards). As mentioned earlier, all these components work together and complement each other, a solid unity through out the process of achieving the needs.

The first component, al-'Ubudiyyah (the needs for devotions) is the most basic human's need in life (Hanapi, 1998: 250). This principle is shown by one's willingness to dedicate himself to Allah, that is, to worship according to the true teachings of Islam (performing prayers, doing charity, fasting, performing Hajj and so on). Next, Talab al-Isti'anah (the needs for supports) is the second component, is shown when one cares about the others and keeps himself away from wrongdoings. This component explains the intentions of every man to possess a safe life, love and affection, the feelings of need or possession, mutual cooperation and respect, family and social life (Hanapi, 1998: 252). The third component, Talab Istiqamah (the needs for the right paths) emphasizes a precise and firm desire to face the realities of life, justice and equality, thus this will lead him regularly on the right paths through out his life journey (Hanapi, 1998: 253). This component enables every man to fulfill his duty as a Muslim gracefully and never turns his back to Him. The fourth component, Talab Hidayah (the needs for guidances) is shown through the hope and willingness of every man to receive guidances from Him (Allah) and through hidayah or guidance, man will benefit from the knowledge and skills he later possesses. The last component of Talab Ni'mah (the needs for rewards) is shown 
when one has a hope to receive some kinds of rewards in any mean applicable to them (children, money, health, happiness, beauty, wealth, simplicity and so on).

The five human's needs according to Imam al-Razi can be seen as in Figure 1 below:

\begin{tabular}{|c|l|l|}
\hline 1. & Al-'Ubudiyyah & The need for devotions \\
\hline 2. & Talab al-Isti'anah & The needs for supports \\
\hline 3. & Talab Istiqamah & The needs for the right paths \\
\hline 4. & Talab Hidayah & The needs for guidance \\
\hline 5. & Talab Ni'mah & The needs for rewards \\
\hline
\end{tabular}

Figure 1: The five components of human's needs, according to al-Razi.

Objectives of this paper:

- To discuss the character of the protagonist in the novel Cucu Tuk Wali.

- To examines the needs of the protagonist from an Islamic perspective in the novel Cucu Tuk Wali.

\section{Al- Razi's Human's Need in the Novel Cucu Tuk Wali}

As mention earlier, this study discusses the needs of the protagonist, Liza, in the novel Cucu Tuk Wali. This study scrutinizes the al-Razi's Islamic theory of human's need as discussed above. The novel presents a story about her struggle to overcome conflicts in her life, thus this would later help her to achieving her needs. To do this, Liza as a Muslimah (a Muslim woman) should have possessed all the components of the theory; Al-'Ubudiyyah (The needs for devotions), Talab al-Isti'anah (The needs for supports), Talab Istiqamah (The needs for the right paths), Talab Hidayah (The needs for guidances) and Talab Ni'mah (The needs for rewards).

\section{Al-'Ubudiyyah (The Needs for Devotions)}

Firstly, to deal with those conflicts, as a Muslim, Liza should have possessed the first component of the theory, al-'Ubudiyyah (the needs for devotions). This is the most basic need in one's life, usually shown when one is willing to dedicate himself to God. This involves mainly the acts of performing prayer in Islam, known as "salat". A Muslim understands very well that if he does not perform salat, then there is no difference between him and the non-Muslims. Therefore, Liza demonstrates the nature and characteristics of a Muslim in her daily life by performing salat regularly and in every salat, she would recite prayers, hoping that God will forever help her in everyday's life. This clearly shows that Liza is trying to be a good person, and to achieve this, she needs to possess good values in life. Al-Ghazali (2003: 9) explains that possessing such values lead to the true perfection of a Muslim. This explains that in order to acquire faith, man needs to show good attitude and morals.

The first instance to show Liza's desire to be a good Muslim is shown at the early phase of the story. As mentioned earlier in the story that once at the university, Liza had fallen in love to Safuan, and at one point, she realizes that this has kept her away from religion and the God. Therefore, she decided to change for betterment, since then starts joining religious classes. The willingness to change indicates here that Liza starts to realize that she should dedicate herself to God. This is clearly in accordance to Hanapi (1998: 250) who emphasizes that the needs for devotion would lead a Muslom closer to his God, Allah. As in the story, the closer 
Liza devotes to God, the more she understands her roles and responsibilies as His caliph and servant.

To explain further on this, the novel indicates that there are number of people who are not willing to follow Liza's footsteps, among them are Safuan and Liza's roommate in university hostel, Tuti. To make matter worse, they instead try to attract her to commit sins. This, however, lead to nothing, as Liza is assertive enough to over-rule them, regardless of the warnings and insults from Safuan. For her, the preach she receives during the religious meetings enable her to understand that the only thing she need to do is to devote herself to God. This is clear in the excerpt below, which shows how Liza rejects Tuti's idea to join her in a disco party:

"You don't go to the disco?"

"I'm not used to it."

"Emm, come with me once in a while."

Liza swallowed some saliva. Disco? What to look for there.

"It's okay, just to release tension. I'm tired of working. We should rest once in a while," replied Tuti confidently. The legs are shaking. I don't know how many men's bodies are clinging to that flirtatious torso...!

"It's not like that, Tuti, there are many other ways to calm your mind."

"Example?"

"Read the Quran."

"Orthodox, village sis!"

Read the village Quran? Urban is when you go to disco? Strange. But be patient, maybe one day she will change. Like me before.

(Morad, 1993: 24)

Based on the excerpt above, Liza's personality which shows good Muslim characteristics is evident when she tries to advise her roommate, Tuti to read the Quran instead of going out to indulge in immorality. This shows that Liza is put to test by having friends who do not help her draw closer to God, even dare to attract her to join them in committing sins. However, Liza is convinced that everyone will have had his own moment to reflect his life and be a better person. Liza still has the belief that Tuti will get her chance in future. This proves that Liza possesses the personality of "al-mukminun". As for Liza, Tuti is a reflection of herself in the past. This is in line with Al-Ghazali (2006: 710) who implies that one is having the personality of "al-mukminun" if he sees weaknesses of others as a reflection of his own. This excerpt also implies that Liza is trying to fulfill her needs as a Muslim by praying for others to change as well.

It is also interesting to note that since her return to the village, Liza is aware that she still needs to attend the religious classes, as it is a mean to improve herself. Amid the conflicts at the university and in her village, Liza keeps reminding herself that God may just want her to take up more challenges in life. The excerpt below shows that amid the hard work she has to deals with at the farms, Liza realized that there should be some time allocated for her to serve the God as can be seen in the excerpt below: 
Liza looked at the wall clock. It's almost 2.00. It's late. Ustazah might feel unease. I'm the one who is late now. Hurry up. Got up now, go to the bathroom. Take a shower. Take ablution and quickly be on the prayer mat. She wished to keep herself devout in salat, but to no avail. The world was spinning in her mind. Liza felt quite torturous. The world kept spinning in her head. Azhar's and Kadir's faces both intruded her mind. Liza felt quite torturous.

(Abu, 1993: 29)

This excerpt shows that Liza feels disturbed while performing salat because of the conflicts. Kadir and Azhar are the two young men in her village who looked down at her to work on the rabbit farming project. They have hurt her once at the youth meeting. She, however, still has the faith, and has the belief that God will always be by her side. She neither gives up nor blames God for the conlicts inflicted in her. As a true Muslim, Liza wants to keep the good work, and for being a faithful and obedient servant as well, this shows that she devotes to God, an important aspect to show how the first component, Al-'Ubudiyyah, is instilled in her.

\section{Talab al-Isti'anah (The Needs for Supports)}

Next, the study shows that Liza has a wish for the love and support from her father, Haji Lah. Haji Lah is naturally a fierce father and regularly inconsistent on anything. At first, Haji Lah scolds Liza and accuses her by saying how ungrateful she is for not wanting to give up the land he once inherits to her. This is done due the reason that Haji Lah wants to use the land for other purposes. Haji Lah even goes further by reminding her daughter the deeds, for he is kind enough to raise her up and allows her to study in university. He says that Liza is so disappointing and now she returns to the village with empty hands. However, the novel implies that the true reason for the failure is that Liza is terribly hurt when her father decides to marry her former schoolmate, of the same age as her and once rivalled her in various school activities. Besides, Liza partly believes that her father does not love her anymore, as she feels that he has backstabbed her for the decision.

As a Muslim, Liza does not wish to oppose her father as it is simply not right to do so. Instead, what Liza needs most amid the conflict is some love and support from Haji Lah, having them so would enable her to pursue other things in her life. Hanapi (1998: 252) stresses the importance of support as the need once secured will help one for a safe life, love and affection, feelings of need or possession, mutual cooperation and respect, family and social life. This explains that the desire to receive loves and supports from her father are the needs Liza wishes to have. Thus, Liza tries to remain obedient and respectful to her father as she is obliged to the teachings of Islam. This coincides with the opinion of Al-Ghazali (2006: 717) that a man who possesses the personality of "al-mukminun" is the one who takes care of the views on fellow Muslims so as not to hurt each other. This would be done by uttering kind words or by remaining silent. Liza's attitude can be examined in the following excerpt:

Well, I was persuaded to eat. I am my father's daughter. I know that. If I disobey him, it is sinful. I know, I learned all that. After all, why do I have to grab that acre of land? To do what? Liza seemed to reflect that to herself.

But even so, it was also hurt to accept the fact. She wished the man standing outside is someone else, so that she would be able to run into her room.

(Abu, 1993: 8) 
Based on the excerpt above, it is clear that Liza is a good child as she does not want to fight over the land she inherited. Liza is willing to give up the land as she does not want to be a rebellious child. Despite her disappointment, she still tries to be gentle when confronting him. This shows that she has a simple need to be fulfilled, that her father would understand and love her.

However, Liza still feels dejected, even after she tells him that she does not want to for the acre of land and she can let it go. It seems to be simple compromise, but yet Haji Lah does otherwise. There is still disagreement between them, as Haji Lah brings up his old deeds in raising up Liza until she is no longer dependent on him, just for the sake of the land. All this however have turned out differently when Liza decides to end the conflict in a good way. She still strives love and support from her father, so that she visits Haji Lah, to let him know that she will forever be his good daughter. As a Muslim, Liza knows that she is obliged to show her love to her parents, even if they are in bad terms.

According to Mohd (1987: 85 - 94) the true nature of a Muslim is to shows ihsan, that is, to do good deeds and serve both parents. Furthermore, every Muslims is responsible to express appreciation to both parents, even if they are not Muslims. This is clearly shown in the novel in one occasion, on her return home once she received news about Haji Lah's illness, as in the excerpt below:

"Who is that, Nab?" The father asked from inside the room.

"Liza. Liza is back, father," said Liza as soon as she saw him.

Liza burst into tears. She lunged at her father who was bedridden.

"I'm sorry, father. I didn't do good to you." Liza kissed her father's hand in tears seeping down her cheeks.

"You are a good child Liza. I always pray for you. I'm sick. Sometimes I am good, and sometimes I am not. Fortunately, I've you stepmom by my side. She is the one who serves me. My own children... emm..." Haji Lah burst to tears. "They have grown up, they are smart kids...," he continued, choking at his words.

There was nothing that Liza could say. She is sad.

(Abu, 1993: 137)

The excerpt shows that there should always be a mutual understanding between the father and the daughter. Liza is clearly a good child as she apologizes for all her wrongdoings to her father and Haji Lah admits that she is always her good child. This also implies that Liza is a youth who possesses the personality of "al-mukminun" (a good Muslim). Although at first both seem selfish and stubborn, they still care about each other. As they start to apologize to each other, Liza's need for his love and support are secured. This is in line with the teaching of Islam, that every child must be obedient to his/her father as is shown in the novel.

\section{Talab Istiqamah (The Needs for the Right Paths)}

The other conflict arises in the story when people of the village slander Liza, thus causes the anger in her father. Both Liza and her sister are deliberately scolded by him. This tarnished Liza's good image, as she keeps herself dignified. As a Muslim youth, she knows that she has to show the personality of "al-mukminun", therefore she is very careful not to hurt her father. As a Muslim, she knows that she has to listen to her father's words, as long as they do not 
contradict the teachings of Islam. This is in line with Al-Ghazali (Intipati Ihya 'Ulumuddin, 2006: 717) who emphasizes that every Muslim should only says good things about the other Muslims, or otherwise he remains silent when he does not have to say anything.

In the novel, Kak Bibah's marriage suddenly falters because of Mak Kiah's slanderous words, who deliberately accuses her to attempt a murder (to her). The matter is getting worse when Haji Lah intervenes, slapping her daughter (Kak Bibah) as if the action may easily end the conflict. As for Liza, that is never a good decision since she believes that Haji Lah should listen to both sides. In Liza's opinion, as a Muslim too, Haji Lah should be patient and find the truth of the story, then he can make judgement wisely. At the same time, Liza does realize that Islam wants every Muslim to give priority to his family, to protect every member and to ensure they would live happily ever after. The need for the right path (Talab Istiqamah) is a need for justice and fairness as well as it would also become the need to be protect oneself from wrongdoings (Hanapi, 1998: 253). However, as always, Haji Lah has taken things in hard ways and never want to tolerate his children.

In another incident, Mak Kiah causes another conflict when she talks bad things about Liza, just because she hates her and her family. Mak Kiah mocks Liza when she knows that Liza's engagement ceremony will involve a small number of people, thus there would be a small feast only for welcome the bride's family. Mak Kiah mocks her further, saying that having a small feast for such ceremony is against the Malay custome. She further accuses Liza for pretending to be Puteri Lindungan Bulan (a character in a fairy tale whose story regularly influence the Malays). Here, Kak Bibah is upset and believes that Mak Kiah has crossed the line too much, as in the excerpt below:

"There are all sorts of things happening since the arrival of Puteri Lindungan Bulan. The guardian of the Puteri Lindungan Bulan must be angry... you know!" Mak Kiah argued louder.

"Subhanallah. What has the Puteri Lindungan Bulan got to do with Liza, Mak Kiah? Try to calm down Mak Kiah. You just show your rotten heart."

"What did you say? I'm showing my rotten heart. Watch your words...! Watch your words, you and your family can't be given face...!" Mak Kiah hurried back home.

(Abu, 1993: 63)

Based on the excerpt, it is clear that Mak Kiah is not satisfied with Kak Bibah's remarks. Later, she tries to avenge her by cutting down a rambutan tree which belongs to Kak Bibah. Kak Bibah responses quickly, getting a stick to hit Mak Kiah. However, Bang Saad manages to stop the fight and tells his wife to be patient. Liza who witnesses the scene feels guilty as it seems that she turns out to be the cause of the fight. This, however, humiliates Haji Lah and he scolds his two daughters, simply because he believes in Mak Kiah's slander words only. It is just as putting salt on his wound since earlier, he is discontented for his small part in Liza's wedding negotiation.

In a whole, all these incidents ruin Liza's family institution. She feels guilty since she is the cause for most of troubles. At the same time, there is no easy solution as well. Her brotherin-law, Bang Saad, still wants to hold a small feast for the wedding while Haji Lah believes 
otherwise. As a result, the conflict puts some distance between them. This clearly shows that Islam also proposes justice in life. For Liza, Kak Bibah and Bang Saad, Haji Lah should be fair to them and to listen to the truth before making his own judgement, which is wrongly done and executed. This is in line with the needs for Muslims, that is the needs for the right paths (Talab Istiqamah), which will help promoting unity and stability, as in the case of Liza's family's conflict.

In her effort to end all the conflicts, Liza later returns home once she gets the news about her father illness. It is a child's obligation to take care of his/her parents, but the meeting between the father and the daughter is more fruitful as Liza apologizes to her father for her wrongdoings. For Haji Lah, as he has obtaimed the truths of the whole conflict later on, he is willing to do the same thing since he knows that he is also wrong for listening and trusting to Mak Bibah's slander words only. This incident shows that Muslim should forgive each other for every wrongdoing, so that they are not bound to being prejudice and will always seek for the right paths only.

\section{Talab Hidayah (The Needs for Guidances)}

The novel also reveals the intention of the protagonist, that is to sharpen her belief in Islam and to impose the same belief to those who are close to her. This can be seen in the story when Liza tries to dictate the teaching of Islam to her former boyfriend, whose misinterpreted her when they were in university. For Safuan, Liza is too extreme to express her Islamic belief while Liza insists that she is on the right path and she always prays for guidance from God.

As Liza is assertive in her remark, it is clear that she is trying to guide Safuan to follow the right path together. She tries to persuade him to join the religious classes together as she has the hope that Safuan one day would be her bridegroom. The failure to achieve this has caused the break up and Liza realizes that nothing she could do for that. For that decision alone, Safuan assumes that Liza is an Islamic extremist and intolerable. Liza insists otherwise and dares to raise up her stance as can be seen in the following excerpt:

"The life here and the hereafter are mutual, Safuan. There is no concept of 50 for now and 50 for the hereafter. What we work for here is what we will receive in return in the hereafter. To succeed in there means that we need to work now," insisted Liza when there was no reaction from Safuan.

"You, Liza, you are an extremist ...!" Safuan responded loudly.

Am I an extremist? And Safuan is simply a normal person. Astaghfirullah. This is weird.

(Abu, 1993: 31)

Based on the excerpt above, Liza is shaken when listening to Safuan's remarks, as if she is the one who is on the wrong path. Being a little bit moderate and still hopeful that Safuan changes his mind, she softens the approach but that does not change him even a lit bit. Therefore, Liza believes that the break up might be good enough for both of them, and she hopes that Safuan one day will receive the guidance by God. Liza's assertiveness on this is in line with Hanapi (1998: 253), who stresses that every man is wishful for the guidance from Him. As a result of this, man would get benefits in the from of knowledge and goods (in multiple forms, such as 
wealth, health and happiness. As for Liza, it is her obligation to make Safuan realizes all these and be guided by God to be a good Muslim.

However, the novel implies that all hope still leads to the dead end. Safuan does not change a bit when the meet again in the story. Safuan neither wants to listen to her nor accepts his ignorance. For this, Liza has decided that there is nothing else she could do, but to end any possibility between them, as can be seen in this excerpt:

"We have long forgotten the afterlife, Safuan. And we have been searching for the material wealth for so long that we have forgotten our goal and place in the hereafter, Safuan. You should be thankful I changed for this. But you are still asking for the same and would like to take me back there again. I'm sorry. We need to break up. My decision is final...!

"Final? Are you sure about this?"

"I will regret if I let this world keep deceiving me because in the hereafter I definitely will not be safe," Liza explained her stance in full strength.

(Abu, 1993: 29)

Based on this passage, Liza and Safuan have to decide that is the end of their love affair. The novel implies that Liza strongly believes that the path that she is leading is the right one and there would not be any better path than the one she has chosen. The path will lead her to be good Muslim as she keeps telling Safuan that that would be her to gain in the hereafter. Hanapi (1998: 253) implies that man should have true instinct the find the truth of his, and this is can only be achieved if Allah, God the Almighty helps him. The guidance from God will enable man to practice good deeds in everyday life and that would be the promised reward in the afterlife.

Liza's assertiveness when dealing the matter with Safuan clearly implies the personality of "al-mukminun" that she possesses. According to Al-Ghazali (2006: 682-683), the overall foundation of good morals and portrayal of good Muslim are wisdom, courage, openness and fairness. Therefore, Liza portrays the self-belief when confronting Safuan, insisting that he is the one that should listen to her advice, and later channel himself to the right path. Her faith turns fruitful as in later in the novel, Safuan feels sorry for his fault and decides to change and seek the truth of Islam.

\section{Talab Ni'mah (The Needs for Rewards)}

The last component of the theory is the needs for rewards, Talab Ni'mah. This is shown in the novel as Liza has always wished the running agricultural project that she is leading will bring success. Although she fails to pursue her study, there is some knowledge on rabbit farming that she has had time to learn while in university. She is hopeful that the project in return will improve the income of some villagers, thus helping to improve their living. To achieve this, she has to study the market and assess rooms for improvement in future. In other words, she dreams of expanding the business nationwide and becomes a successful entrepreneur. This is never easy to her as some youths in the village itself underestimates her capability, as can be seen in the excerpt below:

"But I'm still not sure we can make profit," replied Azhar again. 
"What about the others?"

"I agree with Azhar... woman never knows much!" Kadir agreed with him.

Subhanallah...! They are really envy of me. It's not easy if the idea comes from a woman like me. Hopefully the others would not agree with these two men. Otherwise, what will happen to the little rabbits that she has already bought? The barn is ready and everything that follows has already been planned. Liza bit her lip but pretended that nothing was happening. They deliberately made the wrong judgement. Women are not worthy! Ah that's wrong. This Sinar Mulia youth society, if there are no female youth like me, would have gone a long time ago. Liza's tried to see the whole situation in a better way.

(Abu, 1993: $26-27)$

The excerpt above shows that there will always be challenges for her to turn her dreams to reality. Azhar and Kadir simply rival her for nothing, as they envy of the female youths' project that is led by her. The remarks, however, give extra strength to Liza as she gains more confidence to run and improve the project, and shows to Azhar and Kadir that they are totally wrong to underestimate her capability. This also shows that Liza possesses the personality of "al-mukminun" as she is good in delivering and practicing knowledge, and be patience for any challenges. The knowledge (on rabbit farming) she learned in university is a good asset to run the project and the business and can never be matched by Azhar and Kadir, among the youths who disdains her.

After the success of the rabbit farming project, Liza starts another project that she feels worth the effort and can be easily run by her friends in the youth society. Again, she utilizes the knowledge she learned previously in university, as the next project might give them extra profit and in one way or another, support the rabbit farming project. In her knowledge, the lands in the village are suitable to plant watermelon. To begin with, Liza therefore starts to plant watermelons on her own inherited land:

"Where are you going, Liza?" Kak Bibah asked.

"I want to check the land. When the raining season ends, I want to plant watermelon."

"You... you want to plant watermelon?" Kak Bibah asked her in disbelief.

"Why?"

"It's a hard work. How are you going to water the plant? Are you going to take water in buckets everyday to water them?"

"Insya-Allah, let's see to it first. When I want to start the rabbit farming, is there anybody who has the belief in me? But now, once we become a rabbit supplier, everyone is open his eyes."

"Be careful, the bush is a bit thick."

"Insya-Allah, sister..."

(Abu, 1993: 50) 
The excerpt above implies that Liza is a youth who is good in agricultural and livestock products. She is also highly motivated to be a successful entrepreneur. Therefore, she works hard to practice the skills and knowledge that she has early acquired in Universiti Putra Malaysia. Since joining the youth society in her hometown, she has planned a number of projects that in a long run would benefit them. This also finally lead Azhar to apologize to her, for badmouthing her and for being so bias, never believe in her ability to succeed. The success has also turned out to be an eye opener for villagers to follow her footsteps.

In a nutshell, Liza's faith and determination are paid off as she turns out to be a role model for the community. She also shows the personality of a good Muslim in her ("al-mukminun"). Liza eventually earns a number of rewards (Talab Ni'mah) to herself, her family and her community. Besides, she has also overcome all the conflicts that have long been hindering her capabilities in the eyes of her own family and the community. To fulfill the needs for rewards, Liza has always been a devoted Muslim, who seek help and guidance from God in her prayers and patience, and who has a belief that Allah God the Almighty is the one who can show her the right paths.

\section{Conclusion}

Based on the discussion above, the needs is something that all human try to fullfiled. But as a Muslim, there is a guide for them to follow. It can be concluded that the character of the protagonist in the novel Cucu Tuk Wali was well written. Liza, the character of the protagonist in novel Cucu Tuk Wali written by Abu Hassan Morad has presented the good personality of a Muslim. This study also showed the needs of the protagonist from an Islamic perspective in the novel Cucu Tuk Wali. This study has examines the needs of the protagonist from an Islamic perspective in the novel. It's showed that she has wisdoms to overcome all the obstacles in her life and at the same time, tries to find the best solutions that will suit every party involves in the conflicts. All these too are served with the knowledge that she is a caliph and a servant to Allah, that she always believes in Islam through out her life. The conflicts as a whole make her a more resilient and stronger person that she would be able to fulfil all the needs in her life, namely Al-'Ubudiyyah (the needs for devotions), Talab al-Isti'anah (the needs for supports), Talab Istiqamah (the needs for the right paths), Talab Hidayah (the needs for guidances) and Talab Ni'mah (the needs for rewards). At the end of the story, Liza is clearly turned out to be a character that reader should admire the most.

\section{Theoretical and Contextual of This Research}

Young adult novel's Cucu Tuk Wali by Abu Hassan Morad is not generally about a fiction story but it is show the lifestyle of a Muslim young adult build their character. This study applies the theory encompasses five components of human needs, as proposed by Fakhr al-Din alRazi to recognize and analyse human needs elements in Muslim young adults deal with a number of conflicts in their life.

\section{References}

Abu, H. M. (1993). Cucu Tuk Wali. Kuala Lumpur: Dewan Bahasa dan Pustaka.

Al-Ghazali. (2006). Intipati Ihya' Ulumuddin (Imam Al-Ghazali): Pengajaran Bagi Orang-Orang Mukmin. Al-Syeikh Muhammad Jamaluddin Al-Qasimi Ad-Dimasqi. Translated by Dato' Abu Hassan Din Al-Hafiz. Kuala Lumpur: Darul Fajr.

Al-Razi, F. A. (n. d.). Ma'alim Usul al-Din. al-Qahirah: Matba'ah al-Husayniyyah. 
Hashim, I. (2007). "Sejarah Penulisan Novel di Malaysia: Isu dan Cabaran". Jurnal Pengajian Melayu. Kuala Lumpur: Universiti Malaya. (18) 25- 40.

Halis, A. M. H. (2002). Novel-Novel Zailiani Taslim: Analisis Kehendak Remaja. A Master Thesis. Universiti Putra Malaysia, Serdang.

Halis, A. M. H. (2014). Dinamika Tema dalam Novel Remaja di Malaysia. A Doctorate Thesis. Universiti Putra Malaysia, Serdang.

Halis, A. M. H., Arbaie' S., \& Nik, R. N. M. A. (2017). Kehendak dan Jati Diri Pelajar Islam Malaysia di Turki dalam Novel Rona Boshporus. Seminar Peradaban: Rentas Budaya Melayu dan Turki. 21 March 2017: 1- 20.

Hanapi, M. N. (1998). "Razi's Human Needs Theory: An Exposition of Some Relevent Issues". Essays on Muslim Theology and Philosophy. Bangi: Jabatan Usuluddin dan Falsafah, Universiti Kebangsaan Malaysia. 247- 263.

Haron, D. (2015). Manusia dan Islam. Volume 1 \& 2. Kuala Lumpur: Dewan Bahasa dan Pustaka.

Imam, A. R. (2000). Ruh dan jiwa: tinjauan filosofi dalam perspekstif Islam. Translated by H. Mochtar Zoerni, Joko S. Kahhar. Surabaya: Risalah Gusti.

Imam, R. (1978). Imam Razi's 'Ilm Al-Akhlaq. Translated by oleh M. Saghir Hasan Ma'sumi. New Delhi: Khitab Bhavan.

Julai, U. (1997). Hierarki Kehendak Manusia oleh Maslow dalam Novel-Novel Remaja Terpilih: Satu Perspektif Psikologi Humanistik. Seminar Perkembangan Novel Remaja di Malaysia. Kuala Lumpur: Dewan Bahasa dan Pustaka.

Jumali, H. S. (2011). Pengaruh Urbanisasi Dalam Novel Cucu Tuk Wali Melalui Pendekatan Kemasyarakatan. https://www.researchgate.net/publication/31667834_Pengaruh_ Urbanisasi_dalam_Novel_Cucu_Tuk_Wali_Melalui_Pendekatan_Kemasyarakatan. Access on 28 June 2021, 11:00 p.m.

Jumali, H. S., \& Che, A. C. Y. (2010). Analisis Teks Cucu Tuk Wali Menggunakan Pendekatan Kemasyarakatan. Jurnal Personalia Pelajar. Bangi: Universiti Kebangsaan Malaysia. No. 13 June 2010: 19-36.

Kamus Dewan. (2007). Kuala Lumpur: Dewan Bahasa dan Pustaka.

Mohd, A. H. (1987). Keperibadian Muslim. Kuala Lumpur: Pustaka Salam.

Mohd, M. M. A. (2011). Pemikiran Fakhr Al-Din Al-Razi Tentang Syurga Berdasarkan Tafsir Mafatih Al-Ghayb. Tesis Master. Universiti Malaya, Kuala Lumpur.

Muhammad, A., Indriaty, O., \& Ibrahim, A. B. (2014). Kehendak Manusia: Justifikasi Dan Pengkategorian Berdasarkan Tanggungjawab. Jurnal Islāmmiyyāt. 36(1): 57 - 62.

Nor, R. S. (2006). Falsafah Diri Remaja dalam Novel Remaja Melayu. Kuala Lumpur: Dewan Bahasa dan Pustaka.

Nurhamizah, H. (2015). Psikologi Keperluan Remaja dalam Novel-Novel Remaja Hadiah Sastera Kumpulan Utusan (HSKU). A Doctorate Thesis. Universiti Malaya, Kuala Lumpur.

Syed, M. N. A. (1990). The nature of man and the psychology of the human soul: a brief outline and a framework for an Islamic psychology and epistemology. Kuala Lumpur: ISTAC.

Tang, C. Y. (1990). Psikologi Perkembangan. Kuala Lumpur: Kumpulan Budiman Sdn. Bhd. 